\title{
Inter-sectoral determinants of forest policy : the power of deforesting actors in post-2012 Brazil
}

\section{Kröger, Antti Markus}

2017-03-07

Kröger , A M 2017 , ' Inter-sectoral determinants of forest policy : the power of deforesting actors in post-2012 Brazil ' , Forest Policy and Economics, vol. 77 , pp. 24-32 . https://doi.org/10.1016/j.forpol.2016.

http://hdl.handle.net/10138/231303

https://doi.org/10.1016/j.forpol.2016.06.003

acceptedVersion

Downloaded from Helda, University of Helsinki institutional repository.

This is an electronic reprint of the original article.

This reprint may differ from the original in pagination and typographic detail.

Please cite the original version. 
Inter-sectoral determinants of forest policy: the power of deforesting actors in post-2012 Brazil

Markus Kröger

Forest Policy and Economics, 2016, http://dx.doi.org/10.1016/i.forpol.2016.06.003

Post-print version, for the original, please see:

http://www.sciencedirect.com/science/article/pii/S1389934116301204

Please refer to the original page numbers when quoting the text.

Highlights

- Illustrates how agribusiness has become the key forest policy definer since 2012 in Brazil

- Uses the case of Brazil to illustrate what happens when forest cover is seen as a threat to the need to combat global hunger

- Assessment of differing ways of framing sustainability that promote three different pathways of forest/land use

- Exploration of convergences, conflicts and actor relations between brown economy, green capitalism and socio-environmentalism

- Brazil provides an important case to study how, in practice, the "brown" and "green" economic pathways are converging

- Shows how the forest industry has become a key actor in the brown/green capitalism-alliance

Abstract

Typically, forest policy-analysis focuses on the forest industry; however, this article argues that analysis should take into consideration non-forest economic-political sectors, creating an inter-sectoral analysis of pathways. An analysis of Brazil's recent forest governance changes allows to outline the political dynamics, thrust and ideas that most influence the use of forests in a political economy whose overall developmental and environmental policies are defined primarily by agribusiness. The Brazilian Congress passed a New Forest Code in 2012, greatly relaxing the previous Code from 1965. The law-changing project was an illustration of the tension between the large landholders-lobby, and the new sustainability demands of various sorts of "green economy" proponents. The recent framing of forests by the agribusiness lobby and the Minister of Agriculture are assessed to explain why and how the understanding and pathway of sustainability in relation to forest and other land uses has changed since 2012. Studies on the major impacts of the post-2012 forest laws are also reviewed. A novel approach is taken, uniting an analysis of large-scale agriculture, tree plantation companies, and socio-environmentalists. It is shown how the New Forest Code and other measures that have brought together the agricultural and forestry frontiers, policies and vocabularies in Brazil have made their united analysis necessary. Brazil provides an important case to study how some parts of the "brown economy" and "green capitalism" pathways are supporting each other in practice, and how the forest industry has become a key actor in this alliance, to the detriment of "socioenvironmentalism".

Keywords

- Brazil;

- New Forest Code; 
- Agribusiness;

- Deforestation;

- Green economy;

- Socio-environmentalism

\section{Introduction}

Typically, forest policy-analysis focuses on the forest industry; however, this article argues that it is essential to look at the most powerful groups of land users in order to understand how forest policies actually unfold. I analyze Brazil's recent forest governance changes. The focus on Brazil allows me to outline the political dynamics, thrust and ideas that most influence the use of forests in a political economy whose overall developmental and environmental policies are defined primarily by agribusiness. This approach responds to demands within forestry research to include non-forest sectors in the analysis of forest futures (e.g. Beland Lindahl and Westholm, 2011). It also responds to the argument made in the STEPS' Pathways approach that we need to analyze critically alternative understandings of sustainability (Scoones, 2015).

The Pathways approach treats sustainability and development as essentially political processes that can be analyzed as tensions, or struggles, between competing pathways to sustainability (Leach et al., 2010: 157). The STEPS Pathways approach (Leach et al., 2010) offers a stepwise approach to explore different Pathways. How and what problems are framed, and by whom, are key questions. The current article has two goals: 1) to examine how sustainability is framed by the key actors within the dominant forest use policy in post-2012 Brazil; and 2) to discuss some of the impacts of the different pathways to Sustainability,, as assessed by the academic literature. I add to the Pathways-approach by suggesting that inter-sectoral, or inter-capitalist, analysis of power relations in political economy is essential if we are to understand how truly unsustainable practices - such as illegal deforestation - are able expand and become the dominant pathway (of land and forest use policy).

In Brazil, forests have traditionally been relegated to an inferior position in economic decision-making (Miller, 2007 and Puppim de Oliveira, 2008). In recent years, this process has continued and even gained a greater hold in the form of expanding large-scale agriculture, mining, energy, and infrastructural projects (Fearnside, 2008) - deregulating the Forest Code in 2012 being a defining point in this process (Ferreira et al., 2014). I argue that this development is driven by an alliance of actors that is promoting what I call a "brown economy". This pathway is currently suppressing alternative pathways promoted by local forestdependent groups.

In order to gain support for reducing forest protection, argue Soares-Filho et al. (2014: 364), the group that I call the brown economy proponents (principally the agribusiness lobby), started their problem formulation by claiming that "forest restoration conflicts with agricultural production" (a narrative which Soares-Filho et al., 2014 and Oliveira and Hecht, 2016, among others, argue to be unfounded). This framing of the existing challenges in forest policy and the needs for change was successful - and can thus be considered dominant - as the Forest Code was relaxed. According to many academic studies, the representation of forest cover maintenance as a huge burden on agricultural producers was a key to changing the Forest Code and to pursuing other measures supporting agribusiness. $\underline{2}$

I also examine a pathway that I call "green capitalism", which pursues sustainability primarily via a deeper commoditization and monetization of "natural resources", for example by internalizing the externalities of Economics as "environmental services" (seeM oore, 2015 and Baletti, 2014). Brazil provides an important 
case to study how some parts of the "brown economy" and "green capitalism" pathways are supporting each other in practice, and how the forest industry has become a key actor in this alliance. In practice this is expressed through tree plantations becoming more valuable and replacing natural forests. Conversion from primary or secondary natural forests to tree plantation is a topic seldom addressed in the study of (Brazilian) forest policy. Scholars studying these phenomena typically analyze and write about them as disparate and non-related issues. However, current political and land use dynamics create stronger links between these sectors.

\section{Theoretical framework and methods}

Herein, I use an analytical framework drawing on frame analysis (Perri 6, 2005, Schön and Rein, 1994 and Beland Lindahl, 2008) and the STEPS Pathways approach (Leach et al., 2010). Pathways to sustainability can be briefly defined as possible trajectories for knowledge, interventions and change that prioritize different goals, values and functions (Leach et al., 2010). According to Leach et al. (2010), issues and problems can be framed in diverse ways by different actors. Frames operate on two levels: a) perception - how we see the world, and b) physical action bias which guides, or delimits, physical action with material consequences (see Perri 6, 2005).

Frames are not free-floating. Hence, the content of any framing ought to be interpreted in its historical and

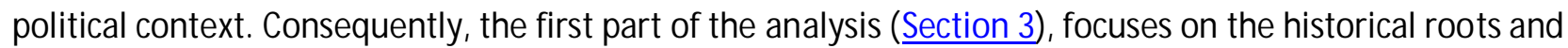
key political dynamics of Brazilian forest-use. This is followed by a brief exploration of the range of actors and pathways that figure in the Brazilian forest policy/land use debate (Section 4). Based on this exploration, a dominant pathway is identified and explored further in Section 5 . The analysis in Section 5 is divided into assessing: a) problem formulation (the issues that are mentioned as future challenges to sustainability in the policy); b) policy goals; c) the framing of implementation procedures; and d) outcomes (how are these described in the policy documents).

The research is primarily based on document analysis and academic literature. The most obvious material for a study of Brazilian forest policy is the New Forest Code (Federal Law 12.727, 2012), and the subsequent Provisory M easures, decrees and actions at federal and state levels that have exemplified and operationalized it. I also consider the public discourses of key forest use actors, focusing on the forest-use narratives of the M inister of Agriculture Kátia Abreu. The reason for this choice of data is that the narratives of these key individuals can reveal how forests are being framed in contemporary Brazil by some of the people in public office with most power in defining land use policies. Op-ed articles, public speeches, and other not so obvious data sources in Portuguese are used to bring to light the underlying understanding of forests by the key actors. $\frac{3}{}$

The document analysis is guided by the framework presented in Fig. 1 of Beland Lindahl et al. (2015). The analysis is supplemented by experiences gained through participant observation and field research since 2003 on the causes of forest cover changes and the expansion of forestry, mining, energy projects and agriculture in several parts of Brazil. The participant observation was conducted, for example, among Amazonian traditional cultural groups and indigenous people and their movements and associations, and within landless movements and forestry, agribusiness and mining companies operating in Brazil. These field research experiences were essential in developing the heuristic tools (brown economy, green capitalism, socio-environmentalism) that help in capturing the peculiarities of the Brazilian context, and provide information about power relations that goes beyond what would be possible solely through document analysis.

\section{Brazil's contemporary forest policy context}


Brazil has a globally unique forest cover (Soares-Filho et al., 2014). It also has a dominant governmentindustry alliance with big ambitions to be, for example: the world's top producer of food, feed, fiber and fuel from soybean (Oliveira, 2016), sugarcane (M cKay et al., 2015) and tree plantations (Kröger, 2016); a key producer of many nonrenewable minerals (Gudynas, 2015); and a champion of hydropower as an alternative to fossil fuels. As all the above large-scale extractivist ${ }^{4}$ land uses impact the sustainability of forest use (Baletti, 2014 and Ferreira et al., 2014), studying them is essential.

I look at how natural forests of different types, particularly those in the central plains (Cerrado) and in the Amazon (but also elsewhere), have been framed (e.g. in the narratives of M inister Abreu cited in Watts 2014). Interestingly, these forests have been described as a threat to productivity and economy in the socio-political and economic-environmental paradigm of Brazil, which has been labeled as neodevelopmentalism. This is a new model of social welfare distribution, based on large-scale resource extraction that has been called neo-extractivism in Latin America (Gudynas, 2015); neo-developmentalism is the Brazilian version of this model (Kröger, 2012). By increasing extraction and directing some of the revenues to populations that are in need, neo-developmentalism unites the desires of resource-extracting elites for greater extraction with the wishes of large groups of the poor to gain access to social welfare. This new political economic and social paradigm has had severe impacts on forest use practices. For example Baletti (2014: 6) argues that neo-extractivism's "leftist rhetoric combined with a real reduction in poverty levels has justified and built support for an economic model rooted in intensified exploitation of natural and agricultural resources".

3.1. Forests in the eyes of typical actors within the "brown economy", "green capitalism", and "socioenvironmentalism" pathways

The "brown economy" is a concept that builds on Gudynas' (2015) description of the new Latin American Left governments as "Brown Lefts", which are neither very red (undertaking deep pro-poor structural or systemic reforms, e.g. massive land distribution to the landless) nor very green (environmentally friendly), but which support extractivist projects that leave behind a brown landscape. "brown economy" does not refer only to the political Left, but can also include the Right-wing: the key feature is the type of landscape change that is pursued.

I propose also two other helpful analytical categories to study Brazil's forest-reliant (and thus alternative or non-dominant) land use groups, frames and pathways. First, I study "green capitalism" as a sub-parcel of the "green economy". By this "capitalist green economy" concept, I refer to the parts of green economy that Levidow (2014) has identified as pursuing a techno-environmental Keynesian or a Schumpeterian green markets agenda.

Second, I study "socio-environmentalists", which in the Brazilian context refers to actors pursuing inhabited forested or mosaic countryside (Hecht, 2011). These include, for example, many forest-dwellers in multipleuse conservation areas, indigenous groups, and other traditional populations, and place-bound social movements or peasants promoting land reform based on agro-ecological principles. These "socioenvironmentalists" do not typically only leave behind them a green landscape (Hecht, 2011), but also the people or societies that have lived traditionally in that nature (which "green capitalism" can exclude, as the work on "green grabbing" has argued [Fairhead et al., 2012]). These groups' preferred pathway to sustainability relies on peasant-like or subsistence-based use of land for family sustenance, without major commodification of nature or practices causing forest-cover change (as their culture and livelihoods depend on these). The concept of "socio-environmentalism" comes from the Brazilian and Latin American socioambientalismo(s), a broad social movement that does not see nature as an obstacle but humans as one part of nature (in contrast to the Cartesian dualism, or "nature"- "society" division). 
According to the "socio-environmentalist" perspective, nature (including human beings dwelling on the local, lived environment) is to be sustained.

Some of the main differences between "socio-environmentalism" and "green capitalism" (as normativeprogrammatic frames and pathways associated with forest use) are the propensity of the latter to try to put a monetary value on nature in terms of "environmental services"; to argue for market-based solutions to sustainability; and to continue within the ontology of Cartesian dualism by trying to "internalize" the "externalities" in Economics (Kosoy et al., 2012). - Note that both the brown economy and green capitalism proponents have as their goal "development". However, in the Latin American context of political ecology, "development" has negative connotations and is associated with negative experiences (Gudynas, 2015). Thus, many socio-environmentalists argue for a "post-development" pathway, where, for example, the traditional pursuit of economic growth via GDP or export increases would not be considered to represent transformations to a sustainable state of affairs.

I have identified above three major groups of actors who promote three alternative (and partly complementary and conflicting) frames and pathways. $\underline{6}$ Social actors can switch between the frames and pathways they adopt and support, although being strongly conditioned by these (Beland Lindahl et al., $\underline{2015}$ ) - I will next discuss more in detail some of the typical actors and their actions that build the pathways.

\subsection{The double movement of increased and relaxed forest protection}

"Socio-environmentalism", as an idea and model of land use, has been framed and turned into programmatic political agendas, particularly since the creation of the Rubber Tapper's M ovement (against deforestation by cattle-ranchers) of Chico M endes at the end of the 1980s, seeking a land use policy where forests and the people living in them were retained (Hecht, 2011). These initiatives promoting (not just discursively) Sustainable forest policies in Brazil have typically emerged from outside the state, more precisely from rural social movements (Kröger, 2013). M obilizations by new social movements and the actions of progressive state actors led to greater protection for the country's forests in the 1988 Constitution (Hochstetler and Keck, 2007). In the 2000s, several politicians fighting against deforestation and supporting the rights of forest dwellers were elected to powerful positions. As a result, Brazil enacted its first Public Forest M anagement Law (Lei 11.284) after a long deliberative process in 2006 (Banerjee et al., 2009). - Particularly during the "Lula" da Silva presidency (2003-2010), large swaths of forestland gained official recognition as some types of conservation areas, including indigenous reserves. These initiatives placed $46 \%$ of the legal Amazon land area under some protection status, and $60 \%$ of these protected lands were governed by local forest dwelling actors (Hecht, 2011), largely in line with the frames and pathways of "socio-environmentalism". Yet, massive deforestation did occur in 2005 in the areas and forest types which were less well protected: only $7 \%$ of the Cerrado and $2.6 \%$ of the Atlantic Forest (both of which are enormously biodiverse biomes) were protected (Soares-Filho et al., 2014).

This period of strengthened regulation to combat deforestation and a generally stronger forest governance framework were not to last for long. In October 2014, President Dilma Rousseff was elected for a second term. The close victory was the result of a collaboration of the Left, consisting principally of such powerful actors within the "socio-environmentalist" alliance as the forest-dwellers movements and landless movements, supporting her. However, after the election, Rousseff's selection of her Cabinet was a disappointment to her supporters in the "socio-environmentalist" and even some other "green economy" groups. She nominated Right-wing politicians famous for their socio-environmentally hostile commentaries as ministers and high-level bureaucrats. ${ }^{8}$ M ost notoriously, Rousseff nominated Kátia Abreu, the leading figure of the Rural Caucus (the "agribusiness lobby") and the President of the Brazilian Confederation of Agriculture (CNA, a lobby group of large landowners), as her M inister of Agriculture. $\stackrel{9}{ }$ These changes in the 
Cabinet supported the "brown economy" pathway (instead of a socially red and/or environmentally green economy). As Soares-Filho et al. (2014: 363) explain, the agribusiness lobby used a substantial reduction in deforestation rates in the Brazilian Amazon as an argument to propose and push through the New Forest Code in 2012. The new Code allows a diminution of environmental protection as outlined below.

\subsection{The New (2012) Forest Code and subsequent laws}

The New Forest Code cut environmental protection in the following ways, as listed by 0 Comitê em Defesa das Florestas e do Desenvolvimento Sustentável (2012). The two most important changes were that:

- Illegal land occupations and forest felling before 2008 were subject to an amnesty, and given the title of "consolidated rural area" (articles $4^{\circ}, 6^{\circ}, 11^{\circ}, 61^{\circ}, 63^{\circ}$ and $67^{\circ}$ ).

- Over $90 \%$ of properties were given amnesty for their environmental debts that would have required them to restore forests. $\underline{10}$

Among other important changes were that:

-Areas of Permanent Protection (APPs), such as forest areas acting as buffers between rivers and plantations or pastures (Riparian Preservation Areas), were reduced by $80 \%$, from 30-500 m to 5-100 m. 11

-APPs on hills (Hilltop Preservation Areas) were removed to great extent, thus allowing erosion e.g. via intensive pasture.

- Mangrove-forest occupations prior to June 2008 were subject to an amnesty, and mangrove-protection areas decreased by $80-50 \%$.

- If owners had not fulfilled the legal requirement of having APPs, there was an amnesty for many (but not for all - there were specific conditions).

-Non-native species can now be used to "restore" natural habitats in the cases where illegal deforestation is detected, and this can be done elsewhere.

-A significant decentralization of power took place, giving governors the power to create or dismantle APPs for example.

On the deforestation-curbing side, the government launched the new CAR-system of Rural Environmental Registry, becoming obligatory by 2017, as a way of monitoring via satellite imagery that the new (relaxed) rules are being followed, and that illegal logging does not take place. If a property does not have a CAR, it cannot receive credit from banks, for example (Law 12.651/2012, §29).

Since 2012, the cutting of environmental regulation has gone even deeper, through state legislations that implement the New Forest Code, such as the PL 219 that resulted in State Law 15.684 in 14 January 2015 in the state of São Paulo. This is a representative state-level forest law that offers implementation procedures for landholders. PROAM ,Instituto Brasileiro de Protecao Ambiental, considers that law 15.684 dramatically worsens the environmental legislation even in comparison to the 2012 Forest Code. $\stackrel{12}{2}$ Law 15.684 allows, for example: 1) creating (supposedly compensatory) Legal Reserves outside of that state where forest is being cut, and thus allows 2) large properties to escape the requirement to maintain Legal Reserves; and 3) endangers the conservation of Cerrados. $\frac{13}{4}$ ) Properties are given 20 years to replant any deforested areas, and replanting may include exotic tree monocultures (such as genetically modified eucalyptus) and lowdensities. $\stackrel{14}{-}$ For these and other reasons, PROAM considers that Law 15.684 repealed the only State Law that made it obligatory to recompose native vegetation in Riparian Preservation Areas following the technical criteria considered correct by Brazil's scientific community. ${ }^{15}$ 
I have identified three major land use groups promoting three competing and partly overlapping frames and pathways. The socio-environmentalist alliance is now under severe attack while an alliance of actors promoting brown economy is gaining influence and power to realize a land conversion-pathway. Here, I want to explore these developments in greater detail. Therefore, I have chosen to focus on the framing of sustainability by those behind the revision of the Forest Code. I direct attention towards the brown economy coalition - a group of social actors who share a brown economy perspective which in turn supports a brown economy pathway.

\section{Different pathways of forest use, the groups behind them, and their interaction}

The ways in which the power balance and links between the pathways of the brown and green capitalist economy have been transformed by the New Forest Code merit further examination, as do the key social actors who support the above pathways (via particular framings), and the conflicts and convergences between these pathways.

\subsection{Arguments defending the "brown economy" perspective}

According to the brown economy proponents who want to expand plantations "to feed the world", "only" about $19 \%$ of the Brazilian Amazon rainforest has been lost according to the official INPE data, $\underline{16}$ while in Western Europe much more forest was cut down historically (see Moore, 2015). Between 1550 and 1970, less than $1 \%$ of the Amazon was deforested. Following the establishment of "brown economy" supporters in dominant positions in the Brazilian government, an attitude of "we have the right to do the same as others" has come to dictate discussions of forest-use ethics in Brazil. The proponents of the "brown economy" suggest that neo-extractivism is a way to secure greater social welfare for large urban populations and democratic majorities, through offering better infrastructure, wages and social security schemes (Gudynas, 2015). The "brown economy" ends up framing "socio-environmentalist" approaches as being minoritarian or representing localist tendencies that are not ethical due to the sparse population density in forestlands (needed to pursue "development", "food security", and "Brazil's growth", for example).

\subsection{Biodiversity versus climate-change mitigating forest perspectives}

There is a wide division within Brazilian forest policy-planning and the implementation of state bureaucracy between those favoring policies that prioritize biodiversity-maximization; and those prioritizing carbon emission-cutting and carbon "storage" (Donadelli, 2014). These two goals are increasingly difficult to reconcile, as illustrated, for example, by the debate around offering CDM (United Nation's Carbon Development M echanism) credits for industrial tree plantations (Plantar, a M inas Gerais-based tree plantation-company, was the first in the world to receive CDM credits), displacing biodiversity-rich areas with tree monocultures (Overbeek et al., 2012). The biodiversity-frame, in alignment with "socioenvironmentalism", is weaker than climate change-mitigation, because it clashes more strongly with the economic interests of agribusiness, mining and energy industries. The proponents of the biodiversity perspective are typically the lower social stratum of society, whose livelihoods depend on non-wood based forest products, agro-ecological farming, and/or indigenous ways of life.

\subsection{Schisms between "green capitalism" and "socio-environmentalism"}

The implicit understanding in "green capitalism" is that capitalism can be accompanied by protection of nature, and can even be used as tool to deliver this aim - and that this is in fact the only realistic way to combat unsustainable land uses. Advocates of "green capitalism" argue that economic argumentation, or creation of large-scale investment alternatives, work best in the Brazilian context to convince the most powerful economic groups to divest from forest-depleting expansion into alternatives. In practice it has 
been hard for the "green capitalists" to convince the popular rural social movements to join them. The underlying schism between the two perspectives partly explains why this is so. Many rural movements are deeply engaged in Liberation Theology-inspired grassroots-socialism, where market mechanisms such as REDD are eschewed, and capitalism is seen as being based on the plundering of nature. In fact, the "green capitalism" pathway has meant more tree plantations, dams and tradable "environmental services" from conservation areas and fewer rural mosaics (Baletti, 2014). Some indigenous groups, however, are siding increasingly with the most powerful "green economy" proponents, in order to receive remuneration for retaining forest cover.

\section{Assessing Brazil's dominant forest policy}

After having identified the range of frames and pathways in the broader debate on land/forest use, I now want to investigate which one could be said to dominate current Brazilian forest policy - and how. I assess policy documents but also talk about various actors, their statements and their activities, resulting in a broader policy analysis (and not simply a document analysis). I assess how "green capitalism" supporters, and the forest industry, are increasingly ending up supporting (knowingly or unknowingly) the "brown economy" pathway and alliance, while "socio-environmentalists" are under huge new pressure, including the threat of violence, to cede their lands to the two other approaches and their proponents.

\subsection{Problem formulation: how are future challenges addressed?}

In line with the frame analysis outlined in Fig. 1 in Beland Lindahl et al. (2015), my analysis here starts by exploring how problems are formulated within Brazil's dominant forest policy. In relation to problem formulation, agribusiness and industrial forestry's frames and goals converge, which has helped to create the new forest policy.

\subsubsection{Agribusiness}

In 2012, there were other major events in Brazil besides the New Forest Code that changed the framing of key terms related to forest sustainability. Rio +20 , the United Nations Conference on Sustainable Development, was supported by the leader of organized agribusiness, Kátia Abreu, as it was "the first time that an environmental conference has included the food question". $\underline{17}$ This move placed "agriculture" as a concept covered by "environmental sustainability", and allowed agriculture to be discussed as a form of environmentalism. After this point, the narratives of Abreu that use the word "environment" seem to have actually focused on talking about increasing agricultural production and particularly agribusiness exports (her main goal), this move suggests the appropriation of the sustainability narrative to further the goals of the dominant (forest) land use policy. The changed meaning given to "environment" (as actually meaning agriculture in Abreu's narrative) is visible for example in what she went on to say in the BBC interview with her on Rio +20 (from which the above quote also comes): "We want to showcase all our projects in the environmental area, our low-carbon agricultural production techniques, which nobody else in the world is doing. I have travelled the entire world and encountered people in awe of Brazil's potential for the production of food". $\underline{18}$

\subsubsection{Industrial forestry}

Agribusiness was not the only powerful actor suggesting that the existing Forest Code is in need of change. Industrial forestry companies operating in Brazil had been lobbying for years to be included under the laxer environmental rules and greater support enjoyed by agriculture, and thus it was natural for them to ally themselves with agribusiness (Kröger, 2013). The tree plantation lobby achieved its goal, and also a more profound transformation of the definition of what constitutes "agriculture" and "forestry". The New Forest Code frames "forestry activities, when undertaken in areas suitable for alternative uses of the soil, to equal 
agricultural activity" (author's translation from Portuguese). Consolidating and specifying this provision, on 11 December 2014 the Brazilian Congress passed the Decree 8.375/2014 ("Defining an Agricultural Policy for Planted Forests").

This new law has hardly been remarked upon. As a result of it, what the law calls "planted forests" can receive the far more flexible legislative benefits and larger amounts of credit that agriculture has enjoyed in Brazil, in comparison to forestry activities in natural forests (or before, in "planted forests"). As one reflection of how the new vocabulary has been incorporated into the language of policy practitioners, Querubini Gonçalves (2014), a lawyer, wrote that after Decree 8.375 "the agricultural activity of forestry will occupy a new status of importance in Brazil's agrarian sector" (2014, my italics, no page numbers).

In the New Forest Code, "planted forests" are no longer under the regulation of the Ministry of Environment, but of the M inistry of Agriculture. The recent laws together allow for a gradual transformation of native forests into planted forests, moving large swaths of land with trees under the power of the Ministry of Agriculture. Thus, that M inistry needs to be studied in detail by those wishing to understand Brazil's forest policy. In particular, the framing of forests by the Minister of Agriculture is an essential issue when analyzing the sustainability of Brazil's forest policy.

\subsection{What are the goals and how are they organized, justified and embedded?}

The goal of Minister Abreu and the "brown economy" is that Brazil would become the world's largest bulk food producer, surpassing the U.S. All factors that are considered as obstacles to the enlargement of agribusiness are framed as being hostile to a key national (and global) project. Socio-environmentalists have given Abreu several nicknames such as "the Chainsaw Queen" and "M iss Deforestation" for her newspaper articles in which she demands that more highways be built in the Amazon, that indigenous territory-creation rights from the President to the Congress are abandoned, and for more planting of intensive monocultures, and terminator GM-crops (Watts, 2014). Socio-environmental activists, on the other hand, are labeled by the CNA (though its president, Abreu) as being led by foreign interests who do not want to see Brazil develop and grow. In this framing, forests and the people defending them are, in Abreu's weighty words, "problems that the agriculture sector faces" (cf. Watts, 2014). Abreu's self-set price for helping Rousseff to govern the country (which is impossible without the support of the powerful Rural Caucus) was for Rousseff

"to understand our situation ... [and problems] and to help solve those problems so we can keep growing ... We cannot rest on our laurels. There are many things holding back progress - the environmental issue, the Indian issue and more. But even with these problems we keep achieving high levels of productivity. Imagine how high they might be without those obstacles" (cf. Watts, 2014).

The framing of forests as a threat and burden has been justified in repeated media articles and news stories in the leading media outlets, such as 0 Globo channels and theFolha de São Paulo journal, where Abreu was a columnist until the end of 2014. In 12 M ay 2012, Abreu argued in her Folha de São Paulo column that Brazil needs to adopt the New Forest Code, as 6.2 million ha of land will be allegedly needed for new cultivation by 2022 for the country to be able to increase grain production by $30 \%$. $\frac{19}{}$ The main argument used by the CNA to urge President Rousseff to participate in dismantling the protection afforded by the Permanent Reserve Areas was that that the price of bulk food would otherwise increase, as there would be no space for expansion. This would go directly against the goal of social equity and eradication of hunger.

In 27 September 2014 Abreu wrote about how disgusted she was with the word "deforestation". According to Abreu the word deforestation has been used before elections as an "environmentalist opium" to blame Brazil and "farmers" wrongly for something that other countries are culpable of, and of which the 
"farmers" are not guilty of. $\underline{20}$ This framing is embedded in the long history of Brazilian modernization narratives and pathways, where forests are an unruly obstacle to be removed by "work" and "technology", and where all who are considered to oppose this project are labeled as "ideological". The framing below by Abreu, from her column, illustrates this type of justification of the dominant forest policy, which is based on an attack on environmentalists: $\underline{\underline{21}}$

The word deforestation has been given a pejorative connotation, as if it signifies a voluntary and wanton destruction of nature. Although this could take place, especially when property is not protected, as happens with the illegal loggers in the Amazon, the reality is very different. If we eat, it is because land has been cultivated and not left in its natural state. Food does not fall from heaven, but is a product of the long work of developing the land. Beautiful, productive landscapes are the result of this transformation of nature. Human beings must be fed and there is a constantly increasing demand for food across the globe. Hunger must be reduced, since the scandal of poverty cannot be tolerated anymore. Even the FAO has alerted the world to the urgency of this question. The global food situation does not allow for ideological approaches. The land must be developed with technology to increase productivity to serve human beings, and Brazil will surely play a key role in this process...

In this framing, forests are not portrayed as sources of food, but as mere obstacles, a vile land use form whose existence, alongside acts of defending forests and maintaining forest cover are framed as morally intolerable as they hamper "food production". This goal and its justification are mostly consistent among those with the greatest power in economic decision-making in Brazil, including prominent Leftist politicians, although major goal conflicts do exist particularly with the "socio-environmentalisms".

\subsection{What are the suggested means to implement the goals?}

\subsubsection{Establishing new commodity chains}

There are many ways to implement the goal of increasing productivity via the expansion of the agricultural, mining and energy frontiers. The Brazilian state Development Bank, BNDES, is a key tool, used to transfer

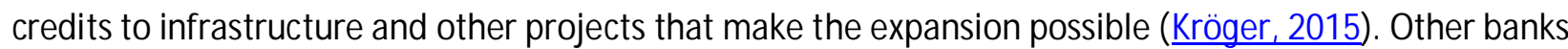
also help in this process.

There is also support from foreign buyers, particularly in China, the EU, and the US. The Four Big agribusiness multinationals, the so-called ABCD: ADM , Bunge, Cargill and Dreyfus, who account for between $75 \%$ and $90 \%$ of global grain trade, take care of the global commodity chain, in conjunction with the government and large landholders (Oliveira, 2016). The government, under President Rousseff, a former minister of Mines and Energy and according to Abreu having a better understanding and appreciation of agriculture than Lula, pushed for new highly contentious large-scale projects as the keys to implement the goals above: for example the establishment of dams for energy production and mines on the Tapajós and other rivers, this government-corporate agency demonstrating multiple arrays of frontier expansion (Kröger and Lalander, 2016).

Besides new investments in "developmental" projects, the goal of +6 million ha of forest being turned into plantations is framed as achievable by further deregulation. Abreu has demanded that FUNAI, the Brazilian Indian Agency, be stripped of its power to demarcate (and retain) indigenous lands, and to also allow for "developing" of other forest areas.

\subsubsection{Appropriation of nature by re-classification and quantification}

In the "new", "nonexistent" and/or "catastrophic" Forest Code (as many analysts call the current legal situation concerning forests, see da Veiga, 2013), the main measures of implementation are based on the principal underlying tasks of capitalism, that is, mapping, quantifying, making calculable, and thus 
governable, nature as "natural resources". Moore (2015) has argued that such new ideas and ways of quantifying and coding nature precede the rise of capitalism. The New Forest Code is a huge calculative, quantifying operation, the largest attempt to actually record all rural properties and make sense of the messy situation where, if all the "rural properties" in different Brazilian private but official land registryoffices (cartórios) are added together, the country's land area does not suffice (overlapping claims being rampant due to land grabbing).

First, the new Code offers as a carrot Payments for Environmental Services (PSAs) to those who simply follow the law. According to da Veiga, who has written extensively on the New Code, this type of sustainability approach "is a great reasoning if we were not in a capitalist society". 르 Yet, PSAs have been also argued to be a potentially fruitful tool to expand conservation in Brazil's difficult setting, where it has been almost impossible to actually implement the Forest Codes due to the resistance by local politicians who favor agriculture (Young and de Bakker, 2014). ${ }^{23}$

Second, all properties must be registered under CAR, Rural Environmental Registry: the state can thus tax these properties (currently the great majority of rural properties do not exist in state registries and thus do not pay taxes) and monitor them. CAR has been considered the only positive opportunity for supporting sustainability in the new Code, if well implemented. $\underline{24}$ This allows increasing taxation and economic growth via the deeper penetration of (state-monitored) capitalism into the countryside. However, in this setting, it will remain much easier to quantify (and tax) agricultural monocrop production than the myriad bio-diverse natural products of forests, suggesting that expansion of capitalism via re-classification of key categories is crucial to implement the main goals.

\subsection{How are outcomes presented, and assessed by research?}

In the dominant forest policy, the outcome is expressed in terms of the increase in value of agricultural production and exports (see e.g. the Ministry of Agriculture's Plano Agrícola e Pecuaria 2013/2014), $\underline{25}$ by expansion of plantations, pasturelands, mines and energy projects (visible e.g. in the framing of ways to attain the goals described above by $M$ inister Abreu, emphasizing the need to grab over $6 \mathrm{M}$ ha from forests for plantations). In contrast, maintenance or an expansion of protected areas or non-agribusiness, nonmining or non-hydropower land uses, are presented as obstacles to development. In the presentation of outcomes, deforestation, land grabbing, slavery, and other forms of violence are denied, hushed-up, or if they are acknowledged, a limited assessment protocol is suggested (Zhouri and Valencio, 2014).

Considering Sustainability, many aspects of the New Forest Code and other post-2012 policies are highly problematic, and I will next discuss some impacts that researchers have already examined.

\subsubsection{Deforestation outcomes}

The 2012 Forest Code gave an amnesty for illegal deforestation to $90 \%$ of rural properties and reduced the Hilltop Preservation Areas (on hilltops, at high elevations, and on steep slopes) by $87 \%$ (Soares-Filho et al., 2014: 363-4). Soares-Filho et al. (2014: 364) found that after 2012, deforestation rates "ceased to decline in the Amazon and Atlantic Forest, and surged in the Cerrado" and that the Code "will allow additional deforestation". Imazon, 0 Instituto do Homem e M eio Ambiente da Amazônia, a leading non-governmental research institute, announced on 27 December 2014 that the rate of deforestation in the Legal Amazon was 427\% higher during the month of November 2014 than during November 2013: the destruction of "degraded forests" increased by $855 \%$ (they also suggest that the real rates may be even higher, as only $67 \%$ of the land area was under surveillance). $\underline{26}$ The official government figures by PRODES also show a notable increase in deforestation in the legal Amazon of $27.6 \%$ between the yearly figures for 2012 $\left(4571 \mathrm{~km}^{2}\right)$ and $2015\left(5831 \mathrm{~km}^{2}\right)$. $\underline{27}$ 


\subsubsection{Changed moral economy}

There are other problems besides increased deforestation in the post-2012 dominant pathway. Given that it is commonplace and very easy to split one's property into smaller farms, so as not to be under the obligation to have legal forest reserves, and that an amnesty was granted retrospectively for criminal acts, land speculators and illegal logging appear to be being supported politically and consistently in the moral economy of forest use. In the absence of political will, the new opportunities for monitoring and legislative tools such as CAR will not be used. It is also worth noting that if CAR is implemented, this will be a boost to the "green capitalist" approach to conceptualizing nature. As Soares-Filho et al. (2014: 364) note, implementing the CAR "could create a trading market for forested lands, adding monetary value to native vegetation". This move would consolidate the position of the "brown economy" by legitimizing their actions and tying the "green capitalism" group to their project, in contravention to "socioenvironmentalism". According to government figures, by September 2015 , about $60 \%$ of the CAR lands had been registered. $\underline{28}$

\subsubsection{Decentralization of power}

The 2012 Code also relaxed forest protection requirements on small properties to almost nothing. One more worrying change was a strong decentralization of decision-making from the Federal government to the states, offering new power particularly to governors. In the São Paulo state, for example, the 2015 Law 15.68429 further relaxed forest protection standards, cutting regulations in the state-level Forest Code. $\underline{30}$ Thus, the new forest policy gives greater leeway for pursuing rapid GDP growth via increasing activities that deplete the forest.

\subsubsection{More tree plantations}

The argument of industrial forestry has thus far been that industrial tree plantations would decrease natural forest cutting (a claim that has not been proved in any studies, see e.g. Nahuelhual et al., 2012 and Kröger, 2014), and that they would retain half of their land area for conservation, which is no longer the obligation (nor has this ever been the case). In the context of Brazil, such claims have never been true, either for the pulp industry that has cut large areas of the Atlantic rainforest and other forests (Kröger, 2013), or for charcoal operations that are sup posedly aimed at decreasing carbon emissions and native forest cuts but in practice ending up dramatically increasing both of these (Sonter et al., 2015).

Despite these facts, the new Forest Code allows an increase in both of these activities; furthermore, it creates new mechanisms that will give added financial incentives to plantation forestry via payments to these for "forest carbon" and "ecosystem services".

\subsubsection{Increased speculation}

The New Forest Code also distorted the categories of land control, these reconceptualizations of legal categories show how deeply embedded sustainability is into the political economy. The new basic category of land control is "rural property". This classification covers $70 \%$ of Brazilian territory, but does not necessarily have anything to do with production, existing often merely for speculative purposes, e.g. in the form of false deeds of land ownerships in the Amazon. "Agricultural establishments", an alternative basic unit of land ownership, cover less than $40 \%$ of Brazil: these can be observed by satellite as they represent those areas of land used for agriculture. According to da Veiga (2013), the twisting of the New Code to take as principal legal entities "rural properties" and not "agricultural establishments" shows that the main goal of the new Code and the subsequent Provisory M easures was to legalize and allow for far greater speculation and future legal deforestation.

\subsubsection{Water scarcity}


Researchers have already noted by empirical studies that the drastic reduction in APP requirements (Permanent Preservation Areas) has led to major problems in river basins, leading to severe water scarcity in the past years (Guimarães et al., 2015). Guimarães et al. (2015) argue by the case of São Paulo that capitalist sectors' unwillingness to leave out land serving for planting as APPs is leading to a very difficult scenario where the provisioning of fundamental basics for sustaining life, such as water, cannot be guaranteed.

\subsubsection{Conglomeration of industrial forestry and agribusiness practices and interests}

Tree plantation companies are finding themselves to be in a key position in the new trade of "forest restoration" requirements, as they can make deals with agricultural landholders to take care of their restoration requirements (and they can also do carbon offset deals to allow deforestation-caused emissions by agriculture). The field trip descriptions of two participants (Jeffries and Heald, 2016) in an event called New Generation Plantations NGP 2016 Encounter, organized by WWF-Brazil, Fibria and Suzano in M arch 2016 in São Paulo, offers an empirical example of how the agricultural and forestry sectors (and the brown and capitalist green economy) are currently converging: $\underline{\underline{1}}$

"In the M ata Atlantica (Atlantic rainforest) area we were visiting, landowners have to restore at least $20 \%$ of their land. Some are willing to do a deal with plantation companies - they will lease some of their land for eucalyptus plantations if the company also takes on the restoration commitment. As a result, large plantation companies like Fibria and Suzano have built up a lot of expertise in forest restoration."

This process of conglomeration supports both the expansion of tree plantations and agriculture. A particularly noteworthy issue is that the practice of planting single-species plantations first and then thinning their trees for industrial purposes, allowing native species to grow under the shade, is a common and growing practice in "forest restoration" in Brazil (Rodriques et al., 2011). There are clear synergies here, but very few have pointed out the potential problems associated with this model of forest restoration by relying on large tree plantation companies. For one, the legitimacy of tree plantations increases, and second, the power and intermeshing of forestry vis-à-vis the agricultural sector augments.

\section{Discussion}

The recent policy changes suggest that, in Brazil, deforestation as an economically compensated and politically protected land use is gaining impetus, in spite of increasing environmental consciousness worldwide. Those groups who had, for centuries, been used to being able to do whatever they wanted with land wished to dismantle the 1965 Forest Code, in the face of it actually starting to be implemented and relied on in the first decade of the twenty-first century as a result of regulatory moves.

The deepening of Brazil's dominant forest policy perspective since the 2012 Forest Code relaxation has given rise to a pathway of deforestation: in this framing of sustainability, agribusiness concerns about food production surpass the forest-based alternative involving food production, biodiversity and protection of traditional cultures and livelihoods that natural forests provide. The rift from the global framing of Sustainability as based on avoiding deforestation (Pülzl et al., 2014) becomes understandable if we examine the Brazilian case as a symptom of the country's political economic power divisions, where the Rural Caucus of large rural landholders with new capitalist ways of intensifying land use and expanding production push the agribusiness frontier, and thus deforest the lands that they crave (Kröger, 2015). The growth in the power of "socio-environmentalism" in the 2000s - visible in increased indigenous and traditional population-controlled territories with legal backing and socio-environmental sustainability in land/forest use - is now being met by a counter-movement. 
These points suggest that it is essential to consider political economy and agribusiness to understand the current forest policies. Brazilian agribusiness' and industrial forestry's attack on forests - these being framed in the attack as a "hindrance" to global social equity in the form of cheap food - have allowed agribusiness to legitimize their model of production and land use, including both huge cattle-ranches with vacant pasture lands and industrial plantations, as the most ethical, just and important activity.

The framing of forests (and their inhabitants) as a problem has also served another goal: to steer attention away from the actions and inaction of large landholders, particularly the maintenance of properties which they did not want to divide. Deforestation was not a necessity, as Brazil has other land available (SoaresFilho et al., 2014). The weakening of the forest laws is directly linked to the long political struggle of trying to avoid agrarian reform that would involve land tenure redistribution. If the new forest laws had not been approved, there could have been demands for deforestation to be paid for by the current "owners", who could be forced to provide recompose for the areas of forest that were destroyed.

Da Veiga (2013) argues that the principal beneficiaries of what he calls "the destruction of the Forest Code" in 2012 were the real estate and land speculators who had appropriated the Cerrado since 1999. In 1999, the Law of Environmental Crimes was passed: but the New Forest Code eradicated the 10 years between 1999 and 2008, legally speaking, thus legitimizing what were illegal activities during this period. The actual goals of the new Code were to avoid payments for deforestation, and the need to legalize land grabs and forest destruction in past (pre-2008) years.

In 2014, Kátia Abreu declared that she has turned from a fierce critic of the Workers' Party under Lula to an ally of the Worker's Party under Rousseff: this happened, according to her, when she saw that in her first 2.5 years Dilma had won back to CNA and agribusiness the losses that they had had to face during the previous 20 years when the demands of environmental protection and social movements were being incorporated into the legal framework and land use changes. 32

\section{Conclusions}

This article has examined the differing forest framings and pathways present in the policy changes and conflicts with respect to land use in post-2012 Brazil. I built on the Pathways-approach (Leach et al., 2007) to investigate how forest policy is defined in a setting where the use of forests is primarily not decided by forest-based policies or groups, but by other sectors. I took a novel approach, uniting an analysis of deforestation activities and industrial tree plantations. Typically, the groups of scholars interested in these areas have remained separate. However, the New Forest Code and other measures that have brought together the agricultural and forestry frontiers, policies and vocabularies in Brazil have made their united analysis necessary. In fact, this article, being first of this kind, has demonstrated that agriculture and forestry are closer than ever in their forest policy framings.

In Brazil, agriculture, mining and energy generation groups have more power to decide what happens with respect to forest cover, and how forest sustainability is framed, than forest-dependent people or forest industries. In this setting, the dominant agribusiness framing of natural forests as a hindrance to development - a "brown economy" pathway - has found an ally in industrial forestry, legitimizing tree plantations by framing them in the New Forest Code as "forests" (for environmentalists) and simultaneously as "agriculture" (to increase production). At the same time, the "brown economy", through its new land use laws, has allowed these tree-planting companies that consider themselves the proponents of a "green economy" to be governed as agriculture, and thus able to escape the stricter forest preservation quotas under which the forestry-sector operated under when still governed as forestry.

The Brazilian example suggests that it is essential to study the political economy as a whole, and consider inter-sectoral linkages, when studying a given policy-arena whose differing pathways to sustainability are 
analyzed. An inter-sectoral, inter-capitalist analysis, where the role of civil society and the state with their various actors, such as the government and bureaucratic institutions, are included, is essential in the study of any sector. Following the Pathways-approach, different countries and actors are seen to promote different understandings of, and pathways to, sustainability, and the power of these also varies. In Brazil, there is a myriad of globally pioneering socio-environmental sustainability-promoting forest-based subpathways within the socioambientalismoapproach, and these gained power spectacularly during the 2000s. But with the rise of global food security as a simply-understood framing of ethical land use, these gains in alternative pathways have become obstacles to the dominant pathway. The resurgence of the resource frontier, ensured by dismantling environmental laws and enshrined in the forestry-agribusiness-nonrenewable industries alliance in a "brown economy", is consuming the space required for maintaining and deepening the Sustainability pathways offered by the socio-environmentalist approaches.

Brazil provides a case to illustrate how forest-pathways to sustainability can be relegated to a secondary position if the most powerful land controlling actors present forests as a threat. The "brown economy" sees forests as an obstacle to "food security"-based agribusiness expansion, global capitalism's need for new mineral resources, and energy production, while the "green capitalism" prioritizes carbon capture over biodiversity and inhabited forests. These framings of sustainability seem to carry an increased weight in defining the forest and land use policies in Brazil, and I do not suppose that Brazil is an isolated case.

\section{Acknowledgements}

I would like to thank Karin Beland Lindahl, Camilla Sandström, the reviewers and the editors for their very helpful feedback. I extend my gratitude as well to Les Levidow and Cadu Young for their brief comments on green economy, and all those interviewed for this study and with whom I have been able to share ideas about Brazilian forest policy changes. This research has been funded by the Academy of Finland projects: "The Politics of Corporate Resource Exploitation: Social M ovement Influence on Paper and M etal Industry Investments in Brazil and India" (grant number 251321); and "Human Ecology, Land Conversion and the Global Resource Economy" (253680).

\section{References}

1.

- Baletti, 2014

○ B. Baletti

- Saving the Amazon? Sustainable soy and the new extractivism

- Environ. Plan. A, 46 (1) (2014), pp. 5-25

2.

- Banerjee et al., 2009

- O. Banerjee, A.J. Macpherson, J. Alavalapati

- Toward a policy of sustainable forest management in Brazil: a historical analysis

○ J. Environ. Dev., 18 (2) (2009), pp. 130-153

3.

- Beland Lindahl, 2008

- K. Beland Lindahl 
- Frame Analysis, Place Perceptions and the Politics of Natural Resource Management: Exploring a Forest Policy Controversy in Sweden

- Sveriges lantbruksuniversitet, Uppsala (2008) (http:// epsilon.slu.se/200860.pdf (Accessed on 2015-01-29))

4.

- Beland Lindahl and Westholm, 2011

○ K. Beland Lindahl, E. Westholm

- Future forests: perceptions and strategies of key actors

○ Scand. J. For. Res., 27 (2) (2011), pp. 154-163

5.

- Beland Lindahl et al., 2015

- K.B. Beland Lindahl, A. Sténs, C. Sandström, J. Johansson, R. Lidskog, T. Ranius, J.M . Roberge

- The Swedish forestry model: more of everything?

- Forest Policy Econ. (2015) http:// dx. doi.org/10.1016/j.forpol.2015.10.012

6.

- Choma, 2014

- J. Choma

- Que tipo de ambientalismo defende Marina Silva?

- (2014) http://blogconvergencia.org/?p=2532 (accessed 5 M ay 2016)

7.

- Da Veiga, 2013

○ J. Da Veiga

- O código e a especulação imobiliária: Especulação imobiliária rural e a nova lei florestal

- (2013) (20 October http://www.observatorioflorestal.org.br/opiniao/o-codigo-eespeculacao-imobiliariain Portuguese)

8.

- Donadelli, 2014

○ F. Donadelli

- Biodiversity and climate change in Brazilian forest policies: the role of ideas

- BRASA XII Conference Presentation, King's College, London (2014) (20-23 August)

9. 
- Fairhead et al., 2012

○ J. Fairhead, M. Leach, I. Scoones

- Green grabbing: a new appropriation of nature?

○ J. Peasant Stud., 39 (2) (2012), pp. 237-261

10.
- Fearnside, 2008
- P. Fearnside
- The roles and movements of actors in the deforestation of Brazilian Amazonia
- Ecol. Soc., 13 (1) (2008), p. 23

11.

- $\quad$ Federal Law 12.727, 2012

- Federal Law 12.727, 17 October 2012; www.planalto.gov.br/ccivil_03/_Ato20112014/2012/Lei/L12727.htm

12.

- $\quad$ Ferreira et al., 2014

- J. Ferreira, et al.

- Brazil's environmental leadership at risk

- Science, 346 (6210) (2014), pp. 706-707

13.

- Gebara, 2015

- M. Gebara

- Brazil: Spoiler or Leader?

- (2015) http:// www.redd-monitor.org/2015/11/05/ guest-post-brazil-spoiler-orleader/ (accessed 6 M ay 2016)

14.

- Gudynas, 2015

- E. Gudynas

- Extractivismos. Ecología, Economía y Política de un modo de Entender el Desarrollo y la Naturaleza

- CEDIB, Cochabamba (2015)

15.

- Guimarães et al., 2015 
- B.B. Guimarães, R.B. Guimarães, A.C. Leal

- Código Florestal brasileiro: análise do conceito de Área de Preservação Permanente e sua aplicação na bacia hidrográfica do Córrego São Pedro-Anhumas, São Paulo

- Boletim Campineiro de Geografia, 5 (1) (2015), pp. 157-173

16.

○ $\underline{\text { Hecht, } 2011}$

○ S. Hecht

- From eco-catastrophe to zero deforestation? Interdisciplinarities, politics, environmentalisms and reduced clearing in Amazonia

○ Environ. Conserv., 39 (1) (2011), pp. 4-19

17.

- Hochstetler and Keck, 2007

- K. Hochstetler, M. Keck

$\circ$ Greening Brazil: Environmental Activism in State and Society

- Duke University Press, London (2007)

18.

- Leffries and Heald, 2016

$\circ \quad$ B. Jeffries, A. Heald

○ Brazil, NGP 2016 Encounter

- (2016) http://newgenerationplantations.org/en/studytours/7 (Accessed 6 May 2016)

19.

- Kosoy et al., 2012

- N. Kosoy, et al.

- Pillars for a flourishing earth: planetary boundaries, economic growth delusion and green economy

- Curr. Opin. Environ. Sustain., 4 (1) (2012), pp. 74-79

20.

- Kröger, 2012

- M. Kröger 
- Neomercantilist capitalism and post-2008 cleavages in economic decision-making power in Brazil

○ Third World Q., 33 (5) (2012), pp. 887-901

21.

- Kröger, 2013

○ M. Kröger

- Contentious Agency and Natural Resource Politics

○ Routledge, London (2013)

22.

- Kröger, 2014

- M. Kröger

- The political economy of global tree plantation expansion: a review

○ J. Peasant Stud., 41 (2) (2014), pp. 235-261

23.

○ Kröger, 2015

- M. Kröger

- O papel do Estado brasileiro na criação de fronteira capitalista e novas naturezas no passado e futuro

- C. Santana, W. Iglecias (Eds.), Estado, burocracia e controle democrático (2015), pp. 171196 (São Paulo: Alameda)

24.

- Kröger, 2016

○ M. Kröger

○ The political economy of 'flex trees': a preliminary analysis

○ J. Peasant Stud. (2016) http:// dx. doi.org/10.1080/03066150.2016.1140646

25.

- $\quad$ Kröger and Lalander, 2016

- M. Kröger, R. Lalander

- Ethno-territorial rights and the resource extraction boom in Latin America: do constitutions matter? 
○ Third World Q., 37 (4) (2016), pp. 682-702

26.

- Leach et al., 2007

- M. Leach, I. Scoones, A. Stirling

- Pathways to sustainability: an overview of the STEPS centre approach

- STEPS Approach Paper, STEPS Centre, Brighton (2007)

27.

- Leach et al., 2010

- M. Leach, I. Scoones, A. Stirling

- Dynamic Sustainabilities: Technology, Environment

- Social JusticeEarthscan, London (2010)

28.

- Levidow, 2014

- L. Levidow

-What green economy? Diverse agendas, their tensions and potential futures

- IKD Working Paper 73, Open University (2014)

29.

- McKay et al., 2015

- B. M cKay, S. Sauer, B. Richardson, R. Herre

- The politics of sugarcane flexing: insights from Brazil, Southern Africa and Cambodia

○ J. Peasant Stud., 43 (1) (2015), pp. 195-223

30.

- Miller, 2007

○ S. Miller

- Environmental History of Latin America

- Cambridge University Press, Cambridge (2007) 
31.

- Moore, 2015

- J.W. Moore

- Capitalism in the Web of Life: Ecology and the Accumulation of Capital

- Verso Books (2015)

32.

- Nahuelhual et al., 2012

- L. Nahuelhual, et al.

- Land-cover change to forest plantations: proximate causes and implications for the landscape in south-central Chile

- Landsc. Urban Plan., 107 (1) (2012), pp. 12-20

33.

- $\underline{\text { O Comitê em Defesa das Florestas e do Desenvolvimento Suste }}$

- O Comitê em Defesa das Florestas e do Desenvolvimento Sustentável

- Comitê avalia novo Código Florestal

- (2012) http:// www.greenpeace.org/brasil/ pt/Documentos/Nota-publica-sobre-o-novoCodigo-Florestal-Brasileiro/ (In Portuguese)

34.

- $\underline{\text { Oliveira, } 2016}$

$\circ$ G. Oliveira

- The geopolitics of Brazilian soybeans

○ J. Peasant Stud., 43 (2) (2016), pp. 348-372

35.

- $\quad$ Oliveira and Hecht, 2016

- G. Oliveira, S. Hecht

- Sacred groves, sacrifice zones and soy production: globalization, intensification and neonature in South America

○ J. Peasant Stud., 43 (2) (2016), pp. 251-285

36.

- $\underline{\text { Overbeek et al., } 2012}$ 
- W. Overbeek, M. Kröger, J. Gerber

- An overview of industrial tree plantations in the global South: conflicts, trends and resistance struggles

- Ejolt Report Number 3 (2012)

37.

- Perri 6,2005

- Perri 6

-What's in a frame? Social organisation, risk perception and the sociology of knowledge

- J. Risk Res., 8 (2) (2005), pp. 91-118

38.

○ $\quad \underline{\text { Pülzl et al., } 2014}$

- H. Pülzl, D. Kleinschmit, B. Arts

- Bioeconomy-an emerging meta-discourse affecting forest discourses?

- Scand. J. For. Res., 29 (4) (2014), pp. 386-393

39.

- Puppim de Oliveira, 2008

- J.A. Puppim de Oliveira

- Property rights, land conflicts and deforestation in eastern Amazonia

- Forest Policy Econ., 10 (2008), pp. 303-315

40.

- Querubini Gonçalves, 2014

- A. Querubini Gonçalves

- A Política Agrícola para Florestas Plantadas

- União Brasileira dos Agraristas Universitário - UBAU (2014) http:// www.ubau.org.br/site/apolitica-agricola-para-florestas-plantadas/

41.

- Rodrigues et al., 2011

- R.R. Rodrigues, S. Gandolfi, A.G. Nave, J. Aronson, T.E. Barreto, C.Y. Vidal, P.H. Brancalion

- Large-scale ecological restoration of high-diversity tropical forests in SE Brazil

○ For. Ecol. Manag., 261 (10) (2011), pp. 1605-1613 
42.

- Schön and Rein, 1994

- D. Schön, M. Rein

- Frame Reflection: Toward the Resolution of Intractable Policy Controversies

- Basic Books, New York (1994)

43.

- Scoones, 2015

- I. Scoones

- Transforming soils: transdisciplinary perspectives and pathways to sustainability

- Curr. Opin. Environ. Sustain., 15 (2015), pp. 20-24

44.

- Soares-Filho et al., 2014

- B. Soares-Filho, et al.

- Cracking Brazil's forest code

○ Science, 344 (6182) (2014), pp. 363-364

45.

- Sonter et al., 2015

- L.J. Sonter, D.J. Barrett, C.J. M oran, B. Soares-Filho

- Carbon emissions due to deforestation for the production of charcoal used in Brazil's steel industry

○ Nat. Clim. Chang., 5 (4) (2015), pp. 359-363

46.

- Stickler et al., 2013

- C.M. Stickler, D.C. Nepstad, A.A. Azevedo, D.G. M cGrath

- Defending public interests in private lands: compliance, costs and potential environmental consequences of the Brazilian forest code in Mato Grosso

- Philos. Trans. R. Soc. B, 368 (2013), p. 20120160

47.

- Watts, 2014

$\circ$ J. Watts

- Brazil's 'chainsaw queen' takes on environmentalists 
- The Guardian, 5 M ay

(2014) http://www.theguardian.com/environment/2014/may/05/brazil-chainsaw-queenkatia-abreu-amazon-deforestation

48.

- Young and de Bakker, 2014

- C.E.F. Young, L.B. de Bakker

- Payments for ecosystem services from watershed protection: a methodological assessment of the oasis project in Brazil

- Nat. Conserv., 12 (1) (2014), pp. 71-78

49.

- Zhouri and Valencio, 2014

- A. Zhouri, N. Valencio

- Formas de matar, de morrer e de resistir: Limites da resolução negociada de conflitos ambientais

- Editora UFM G, Belo Horizonte (2014) (In Portuguese)

Leach et al. (2007: 18) differentiate Sustainability (with a capital S) from sustainability as "the capability of maintaining specified values of human wellbeing, social equity and environmental quality over indefinite periods of time".

\section{$\underline{2}$}

For example, Stickler et al. (2013: 1) argue that "The perceived economic burden of BFC [the pre-2012 Brazilian Forest Code] compliance on soya bean and beef producers (US\$3-5.6 billion in net present value of the land) may in part explain the massive, successful campaign launched by the farm lobby to change the BFC".

$\underline{3}$

For example, I analyzed the forest-use narratives of the current M inister of Agriculture's op-ed articles in Brazil's top newspaper, Folha de São Paulo.

$\underline{4}$

By "extractivist" I refer here to an ideology and practice that seeks to extract as much of a resource as possible from an area in as short a time as possible. During the commodities super-cycle of 2007-2014, extractivist stances forged the extractivisms of different countries - there are also variations in degrees and styles of extractivism (Gudynas, 2015). 
Traditionally, economics has considered the damage caused to the environment to be an "externality" that has not been included in analysis - environmental economists argue that by including such hidden costs in their calculations, the externalities can be "internalized" and thus Economics could serve to address problems such as climate change (in which it has failed, due to "externalization"-based policy advice, according to Moore, 2015).

\section{$\underline{6}$}

Each of the groups has major internal sub-groups, framings and sub-pathways: for "green economy", which I have here divided into "green capitalism" and "socio-environmentalism", see Levidow 2014. For different "brown economy" strands, seeGudynas (2015).

\section{$\underline{7}$}

The law covers $22 \%$ of the national territory; Article 35 of the law has been disparaged by the critiques of "green capitalism" (e.g. in Choma 2014), as it allows the concession of public forests to private initiative for up to 40 years, for example for timber extraction, although e.g. in the Amazon these forests are inhabited by peasants.

\section{$\underline{8}$}

http://www.viomundo.com.br/politica/andre-singer-presidente-parece-uma-personagem-dekafka.html (accessed 2 March 2016).

http:// www.cartacapital.com.br/politica/dilma-a-direita-perplexa-e-a-esquerda-indignada1211.html (accessed 2 March 2016).

$\underline{10}$

This measure "decreased the total area to be restored from $50 \pm 6$ to $21 \pm 1$ M ha", most of which was composed of Legal Reserve areas, and located in the Amazon,Cerrado, and the Atlantic Forest ( Soares-Filho et al., 2014: 363). The 2012 Code also maintained a prior allowance which permits " $88 \pm 6 \mathrm{M}$ ha of legal deforestation on private properties" - the size of this area is huge and exceeds the area that has to be conserved as Legal Reserves and Riparian Preservation Areas (Soares-Filho et al., 2014).

\section{$\underline{11}$}

Estates with up to one fiscal module (this varying between 5 and 110 ha depending on the municipality), for example, are required to leave only $5 \mathrm{~m}$ of Riparian Preservation Areas (before this was 30 m). http://www.terrabrasilis.org.br/ecotecadigital/images/abook/pdf/2sem2015/outubro/Out.15.02.pd f (accessed 10 May 2016).

\section{$\underline{12}$}

http:// www.proam.org.br/acontecimento.asp?ID=113 (accessed 9 M ay 2016).

\section{$\underline{13}$}

http:// www.observatorioflorestal.org.br/opiniao/esta-na-hora-de-acabar-com-lei-que-protege-florestas-emananciais (accessed 2 March 2016). Observatório do Código Florestal was created in M ay 2013 by seven civil institutions (large research and environmental organizations) to monitor the implementation of the new Forest Code; it offers for example a website with news on the topic. 
http:// www.observatorioflorestal.org.br/noticia/em-seis-meses-menos-de-10-dos-propriedades-ruraisentraram-no-car (accessed $2 \mathrm{M}$ arch 2016).

\section{$\underline{15}$}

http://www.proam.org.br/acontecimento.asp?ID=113 (accessed 9 M ay 2016).

$\underline{16}$

http://rainforests.mongabay.com/amazon/deforestation_calculations.html (accessed 3 M arch 2016).

\section{$\underline{17}$}

http://www.bbc.com/portuguese/ noticias/2012/06/120614_entrevista_katia_jf.shtml(Accessed 4 M arch 2016, author's translation from Portuguese).

$\underline{18}$

http://www.bbc.com/portuguese/ noticias/2012/06/120614_entrevista_katia_jf.shtml(Accessed 4 March 2016, author's translation from Portuguese).

$\underline{19}$

However, considering actual Sustainability, argues da Veiga (2013), this framing is not based on facts, as Brazil has over 211 million ha of pasture-land, a large slice of which could be turned into plantations: so there would in fact be no need to attack forest protection and biodiversity (see also Oliveira and Hecht, 2016).

\section{$\underline{20}$}

In these framings, Abreu renders agribusiness as a non-agentive non-actor, and does not admit any land grabbing, murders or other violations of human rights and environmental laws, whose breaches are well documented and observable by anyone in the field in Brazil (see e.g. Zhouri and Valencio, 2014).

\section{$\underline{21}$}

http:// www1.folha.uol.com.br/colunas/katiaabreu/2014/09/1523399-desmatamento-

eleitoreiro.shtml (accessed 2 March 2016) (Translated by the author).

\section{$\underline{22}$}

http://www.iniciativaverde.org.br/comunicacao-artigos-e-noticias-detalhes/jose-eli-da-veiga-o-debatesobre-o-codigo-florestal-continuara (accessed 9 M ay 2016).

\section{$\underline{23}$}

If the natural functions of forests that previously did not have a price associated with them will be monetized, this will have major impacts in many senses, argue Levidow (2014) and Moore (2015).

\section{$\underline{24}$}

http://www.iniciativaverde.org.br/comunicacao-artigos-e-noticias-detalhes/jose-eli-da-veiga-o-debatesobre-o-codigo-florestal-continuara (accessed $2 \mathrm{M}$ arch 2016).

$\underline{25}$

http://www.agricultura.gov.br/arq_editor/file/acs/PAP20132014-web.pdf (accessed 2 M arch 2016). 
http://amazonia.org.br/2014/12/ desmatamento-na-amaz\%C3\%B4nia-tem-alta-de-427-em-novembro-dizimazon/ (accessed 2 March 2016).

\section{7}

http://www.obt.inpe.br/prodes/index.php (accessed 9 March 2016). However, it has to be remembered that the figures for current total deforestation in the Amazon were much lower in 2015 than they were in the heyday of deforestation - so the policy setting of the 2012-2015 period has to be given credit for not completely and suddenly reverting back to business as usual. This relatively modest increase in forest conversion into agriculture may partly explain why the dominant political economic groups, allegedly led by vice-president Temer and PSDB, started an impeachment process (criticized as a coup) against the Workers' Party-led government in 2016.

\section{$\underline{28}$}

http://www.observatorioflorestal.org.br/sites/default/files/boletim informativo car setembro 2015.pdf ( accessed 2 March 2016).

\section{$\underline{29}$}

http://www.al.sp.gov.br/ repositorio/legislacao/lei/2015/lei-15684-14.01.2015.html(accessed 9 M ay 2016).

$\underline{30}$

http:// www.al.sp.gov.br/propositura/?id=1198504 and http:// www.observatorioflorestal.org.br/noticia/re gulamentacao-de-protecao-de-florestas-em-sp-falha-em-pautar-grande-imprensa (accessed $2 \mathrm{M}$ arch 2016).

\section{1}

NGP can be considered as an exemplary of the dominant form of "capitalist green economy" in Brazil, and illustrates that both international conservation organizations and forestry companies are at the core of this pathway. NGP argues that its goal is to promote "well managed, designed, inclusive and profitable plantations by sharing knowledge and experience" http://newgenerationplantations.org/en (accessed 6 M ay 2016). In its webpages, NGP highlights the use of voluntary market mechanisms such as FSC and GRI as central tools. This framing of sustainability is in line with the Schumpeterian framing of the pathway to green economy.

\section{$\underline{32}$}

http://www.bbc.co.uk/portuguese/noticias/2014/12/141215_katia_abreu_nomeacao_rm (accessed 2 $M$ arch 2016). A figure that illustrates well the practical impacts of the Brazilian government's turn in its forest policy is the commitment of forest restoration: the 2012 Forest Code reduced $58 \%$ of the previous legislation's target for restoring degraded areas with forests (to 21 million ha). However, in the 2015 Paris climate conference, President Rousseff pledged that Brazil would restore and reforest only 12 million ha, which is much below even the New Forest Code demands (Gebara 2015). 